\title{
Penggunaan Model Pembelajaran Make A Match Sebagai Upaya Meningkatkan Prestasi Belajar Bahasa Indonesia
}

\author{
I Wayan Wijendra ${ }^{1}$ \\ 'SMP Negeri 2 Payangan, \\ Gianyar, Indonesia \\ email: iwayanwijendra@gmail.com
}

\begin{abstract}
Abstrak
Penelitian ini dilaksanakan di SMP Negeri 2 Payangan di kelas VII B yang kemampuan siswanya untuk pelajaran Bahasa Indonesia cukup rendah. Tujuan penulisan penelitian tindakan kelas VII B ini adalah untuk mengetahui apakah model pembelajaran Make A Match dapat meningkatkan prestasi belajar siswa. Metode pengumpulan datanya adalah tes prestasi belajar. Metode analisis datanya adalah deskriptif baik untuk data kualitatif maupun untuk data kuantitatif. Hasil yang diperoleh dari penelitian ini adalah model pembelajaran Make A Match dapat meningkatkan prestasi belajar siswa. Ini terbukti dari hasil yang diperoleh pada awalnya mencapai nilai rata-rata 66,40 , pada siklus I mencapai nilai rata-rata 71,87 dan pada siklus II mencapai nilai rata-rata 81,71 . Kesimpulan yang diperoleh dari penelitian ini adalah model pembelajaran Make A Match dapat meningkatkan prestasi belajar Bahasa Indonesia siswa kelas VII B SMP Negeri 2 Payangan.
\end{abstract}

Kata Kunci: Model Pembelajaran Make A Match, Prestasi Belajar Bahasa Indonesia.

\begin{abstract}
This research was conducted at SMP Negeri 2 Payangan in class VII B, where the students' ability to learn Indonesian is quite low. The purpose of this class VII B action research was to determine whether the Make A Match learning model could improve student achievement. The data learning method is a learning achievement test. The data analysis method is descriptive both for qualitative data and for quantitative data. The results obtained from this study are the Make A Match learning model can improve student achievement. This is from the results obtained at first reaching an average value of 66.40 , in my cycle it was proven that it reached an average value of 71.87 and in the second cycle it reached an average value of 81.71 . The conclusion from this research is that the Make A Match learning model can improve the Indonesian learning achievement of class VII B students of SMP Negeri 2 Payangan.
\end{abstract}

Keywords: Make A Match Learning Model, Indonesian Language Learning Achievement.

\section{Pendahuluan}

Pendidikan merupakan suatu hal yang penting dalam menjadikan manusia yang berilmu, berbudaya, bertakwa serta mampu menghadapi tantangan masa datang. Pendidikan tersebut juga akan melahirkan peserta didik yang cerdas serta mempunyai kompetensi dan skill untuk dikembangankan ditengah-tengah masyarakat. Untuk mewujudkan hal demikian tidak terlepas dari faktor penentu dalam keberhasilan peserta didik dalam pendidikan. Salah satu faktor utamanya adalah kemampuan guru dalam menggunakan model pembelajaran dalam proses pembelajaran.

Guru dalam konteks pendidikan mempunyai peranan yang besar dan strategis. Hal ini disebabkan gurulah yang berada di barisan terdepan dalam pelaksanaan pendidikan. Gurulah yang langsung berhadapan dengan peserta didik untuk menstranfer ilmu pengetahuan dan teknologi sekaligus mendidik dengan nilai-nilai positif melalui bimbingan dan keteladanan.

\footnotetext{
*Corresponding author.
}

Received 03 Februari 2020; Accepted 31 July 2020; Available online 1 September 2020 (c) 2020 MPI. All Rights Reserved 
Tugas guru dari hari ke hari semakin berat, seiring dengan perkembangan ilmu pengetahuan dan teknologi. Guru sebagai komponen utama dalam pendidikan dituntut untuk mampu mengimbangi bahkan melampaui perkembangan ilmu pengetahuan dan teknologi yang berkembang dalam bermasyarakat. Melalui sentuhan guru di sekolah diharapkan mampu menghasilkan peserta didik yang memiliki kompetensi tinggi dan siap menghadapi tantangan hidup penuh dengan keyakinan dan percaya diri.

Salah satu tugas guru di sekolah adalah mengelola proses pembelajaran. Pembelajaran adalah proses interaksi siswa dengan pendidik dan sumber belajar pada suatu lingkungan belajar. Pembelajaran merupakan bantuan yang diberikan guru agar dapat terjadi proses memperoleh ilmu dan pengetahuan, penguasaan kecakapan, pembentukan sikap dan kepribadian peserta didik. Pembelajaran merupakan peristiwa sehari-hari di sekolah. Belajar merupakan hal yang kompleks. Kompleksitas belajar tersebut dapat dBahasa Indonesiandang dari dua subjek, yaitu siswa dan dari guru (Dimyati dan Mudjiono, 2013: 17).

Pemberlakuan pelajaran Bahasa Indonesia diarahkan untuk proses meningkatkan pemahaman dan kemampuan siswa menganalisis sehingga dapat membantu siswa untuk memperoleh pemahaman yang lebih mendalam. Proses pembelajaran Bahasa Indonesia yang terjadi selama ini sering terjadi permasalahan. Permasalahan yang sering timbul selama ini di lapangan adalah cara mengajar guru yang sering menggunakan metode konvensional dan menjelaskan materi sesuai dengan yang ada di buku paket maupun LKS. Selain itu, dalam proses pembelajaran guru belum menggunakan model pembelajaran yang mendukung dalam penjelasan materi.

Kondisi yang sama juga terjadi di SMP Negeri 2 Payangan Berdasarkan hasil observasi yang peneliti lakukan, dapat diketahui bahwa pembelajaran Bahasa Indonesia di kelas VII B masih dilakukan secara konvensional. Metode yang digunakan masih dengan metode ceramah, yaitu siswa hanya mendengarkan pada saat guru sedang menjelaskan, proses pembelajaran hanya berpusat pada guru. Akibatnya prestasi belajar siswa hanya mencapai nilai rata-rata 66,40.

Menghadapi kondisi yang sangat mengkhawatirkan, maka perlu adanya upaya perbaikan dalam proses pembelajaran agar dapat meningkatkan keterampilan proses dalam pembelajaran Bahasa Indonesia yaitu khususnya pada kemampuan analisis dalam memahami materi Bahasa Indonesia. Salah satu alternatif yang digunakan yaitu dengan menggunakan model pembelajaran Make A Match. Dengan penerapan model pembelajaran Make A Match diharapkan kemampuan analisis siswa dapat meningkat.

\section{Metode Penelitian}

Penelitian ini adalah penelitian tindakan kelas. Penelitian tindakan kelas dirancang dalam beberapa siklus, dengan masing-masing siklus terdiri dari 3 kali pertemuan. Rancangan penelitian ini mengacu berdasarkan model yang dikemukakan Kemmis dan MC Taggart (Agung, 2005:91) "Dalam model PTK ini ada empat tahapan pada siklus penelitian, keempat tahapan tersebut terdiri dari: perencanaan, tindakan, observasi/evaluasi, dan refleksi". Pelaksanaan penelitian ini dilakukan dalam bentuk siklus yang dapat digambarkan dalam model seperti gambar sebagai berikut. 


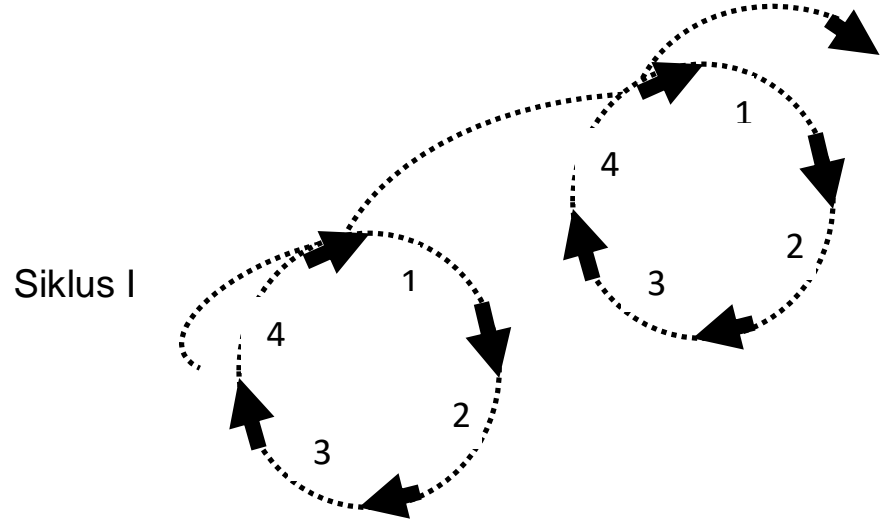

Siklus II

Keterangan:

1. Perencanaan

2. Tindakan

3. Obsevasi/evaluasi

4. Refleksi

Gambar 1. Model PTK dalam Dua Siklus (Agung, 2005)

Pada daur I dimulai dengan adanya ide awal akibat temuan dan analisis yang telah dilakukan. Setelah ada temuan tersebut dibuatlah perencanaan umum sesuai langkah yang direncanakan baik tindakan 1, tindakan 2 maupun tindakan 3 . Sesudah membuat perencanaan, diimplementasikan dalam tingkat 1, dimonitoring implementasinya serta efeknya kemudian dijelaskan kegagalan-kegagalan yang ada selama implementasinya lalu dibuat revisi umum untuk perencanaan tindakan selanjutnya.

Pada tindakan selanjutnya, perencanaan yang telah dibuat diimplementasikan, terus dimonitor implementasinya serta efek yang ada, dijelaskan setiap langkah implementasinya dan efeknya.

Setelah mengetahui bagaimana hasil dan efeknya, dibuat lagi perencanaan untuk tindakan selanjutnya. Demikian beranjut sampai menemukan hasil yang sesuai tujuan yang direncanakan.

Pengumpulan data dalam penelitian ini menggunakan tes prestasi belajar. Tes prestasi belajar berupa tes soal isian maupaun esay. Untuk menganalisis data hasil penelitian ini digunakan metode deskriptif. Untuk data kuantitatif dianalisis dengan mencari mean, median, modus, membuat interval kelas dan melakukan penyajian dalam bentuk tabel dan grafik.

Indikator keberhasilan penelitian yang diusulkan dalam penelitian ini pada siklus I dan II mencapai nilai rata-rata 75,00 dengan ketuntasan belajar $85 \%$. dengan KKM yang ditetapkan untuk mata pelarajan Bahasa Indonesia pada SMP Negeri 2 Payangan adalah 72.

\section{Hasil Dan Pembahasan}

Salah satu indikator keberhasilan pembelajaran dapat dilihat dari prestasi belajar siswa. Djamarah (1994:23) mendefinisikan prestasi belajar sebagai hasil yang diperoleh berupa kesan-kesan yang mengakibatkan perubahan dalam diri individu sebagai hasil dari aktivitas dalam belajar. Kalau perubahan tingkah laku adalah tujuan yang mau dicapai dari aktivitas belajar, maka perubahan tingkah laku itulah salah satu indikator yang dijadikan pedoman untuk mengetahui kemajuan individu dalam segala hal yang diperolehnya di sekolah. Dengan kata lain prestasi belajar merupakan kemampuan-kemampuan yang dimiliki oleh siswa sebagai akibat perbuatan belajar atau setelah menerima pengalaman belajar, yang dapat dikatagorikan menjadi tiga ranah, yakni ranah kognitif, afektif, dan psikomotor.

Model pembelajaran yang cocok diterapkan untuk meningkatkan prestasi belajar Bahasa Indonesia siswa adalah model pembelajaran Make A Match. Huda (2012: 135) mengatakan Make A Match merupakan salah satu pendekatan konseptual yang mengajarkan siswa memahami konsep-konsep secara aktif, kreatif, efektif, interaktif, dan menyenangkan bagi siswa sehingga konsep mudah dBahasa Indonesiahami dan bertahan lama dalam struktur kognitif siswa. Tujuan dari pembelajaran dengan model make and match adalah untuk melatih peserta didik agar lebih cermat dan lebih kuat pemahamannya terhadap suatu materi pokok (Fachrudin, 2009: 168). 
Berdasarkan penelitian yang telah dilakukan dengan menerapkan model pembelajaran Make A Match didapatkan hasil bahwa: Pada siklus I rata-rata nilai prestasi belajar bahasa Indonesia siswa sebesar 71,87 dari jumlah nilai secara klasikal 2300 seluruh siswa SMP Negeri 2 Payangan, dan prosentase ketuntasan belajarnya adalah $75 \%$, yang tidak tuntas adalah $25 \%$. Hasil ini belum maksimal, karena belum mecapai indikator keberhasilan penelitian yang mencanangkan dengan minimal prosentase ketuntasan belajar $85 \%$.

Dikarenakan hasil pada siklus I belum maksimal, maka penelitian dilanjutkan pada siklus II. Hasil yang didapatkan pada siklus II adalah rata-rata bahasa Indonesia siswa sebesar 81,71 dan ketuntasan belajarnya adalah 96,87\%. Dari keseluruhan jumlah siswa yaitu 32 orang siswa 31 orang siswa telah mampu melampaui nilai KKM yaitu 72 . Hasil ini mengindikasikan indicator ketuntasan pada penelitian telah tercapai dan siklus dihentikan.

Seluruh hasil pada penelitian ini dapat digambarkan pada grafik berikut.

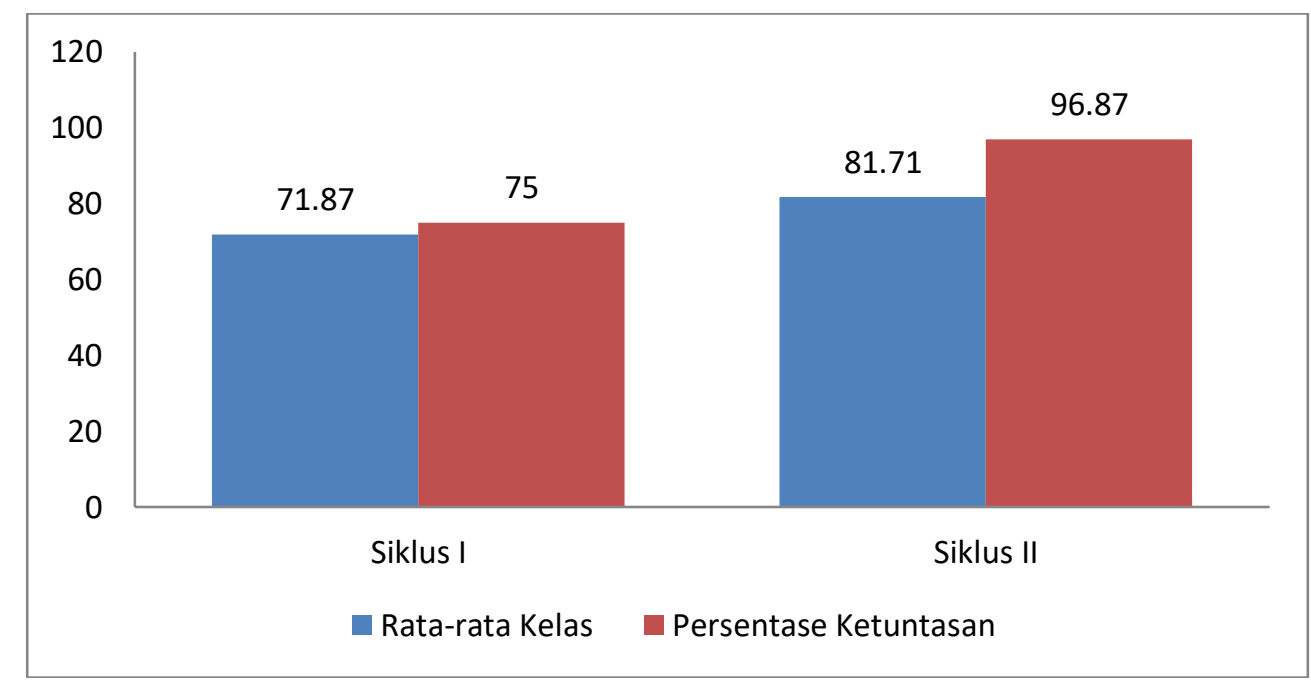

Grafik 1. Grafik Histogram Prestasi Belajar Bahasa Indonesia siswa kelas VII B semester I tahun pelajaran 2018/2019 SMP Negeri 2 Payangan

Hasil penelitian ini sejalan dengan hasil penelitian yang dilakukan oleh Maulandhiyani, dkk (2018) dengan judul Penerapan Model Pembelajaran Make A Match Untuk Meningkatkan Hasil Belajar Siswa. Hasil penelitian menunjukkan, penggunaan model pembelajaran kooperatif tipe Make $A$ Match dapat meningkatkan hasil belajar siswa yang lebih tinggi dibandingkan pembelajaran konvensional.

Nurhidayah, dkk (2017) dengan judul Penerapan Model Pembelajaran Kooperatif Tipe Make A Match untuk Meningkatkan Hasil Belajar Siswa Pada Materi Keragaman Suku Bangsa Dan Budaya. Dalam penelitiannya disimpulkan bahwa penerapan model pembelajaran kooperatif tipe Make A Match secara efektif dapat meningkatkan hasil belajar siswa pada materi Keragaman Suku Bangsa Dan Budaya.

Selanjutnya penelitian yang dilakukan oleh Aliputri (2018) dengan judul Penerapan Model Pembelajaran Kooperatif Tipe Make A Match Berbantuan Kartu Bergambar Untuk Meningkatkan Hasil Belajar Siswa. Hasil penelitian menunjukkan bahwa penggunaan media kartu gambar dapat meningkatkan hasil belajar IPS tentang kegiatan ekonomi bagi siswa kelas IV SD N Wulung 1 Blora.Dalam kondisiawal hanya mencapai $51 \%$, maka pada siklus pertama meningkat menjadi 90\% dan pada siklus II meningkat menjadi 94\%. Berdasarkan hasil penelitian ini, disarankan bagi guru sosial untuk mencoba menggunakan model Make A Match dengan media kartu gambar di kelas IV sampai meningkatkan hasil belajar siswa. 


\section{Simpulan}

Hasil yang diperoleh dari penelitian ini adalah model pembelajaran Make A Match dapat meningkatkan prestasi belajar siswa. Ini terbukti dari hasil yang diperoleh pada awalnya mencapai nilai rata-rata 66,40, pada siklus I mencapai nilai rata-rata 71,87 dan pada siklus II mencapai nilai rata-rata 81,71. Kesimpulan yang diperoleh dari penelitian ini adalah model pembelajaran Make A Match dapat meningkatkan prestasi belajar Bahasa Indonesia siswa kelas VII B SMP Negeri 2 Payangan.

\section{Daftar Pustaka}

Aliputri, Dhestha Hazilla. 2018. Penerapan Model Pembelajaran Kooperatif Tipe Make $A$ Match Berbantuan Kartu Bergambar Untuk Meningkatkan Hasil Belajar Siswa. Jurnal Bidang Pendidikan Dasar (JBPD), Vol.2 No. 1A.

Arikunto, Suharsimi, Supardi, Suhardjono. 2006. Penelitian Tindakan Kelas. Jakarta: PT. Bumi Aksara.

Badan Standar Nasional Pendidikan. 2006. Panduan Penyusunan Kurikulum Tingkat Satuan Pendidikan. Jakarta: BSNP.Depdiknas. 2007. Peraturan Menteri Pendidikan Nasional No. 16 tahun 2007 tentang Kualifikasi Akademik dan Kompetensi Guru. Jakarta: Depdiknas.

Depdiknas. 2005. Peraturan Pemerintah Nomor 19 tahun 2005 tentang Standar Nasional Pendidikan. Jakarta: Depdiknas.

Depdiknas. 2007. Peraturan Menteri Pendidikan Nasional No. 41 tahun 2007 tentang Standar Proses Pendidikan Dasar dan Menengah. Jakarta: Depdiknas.

Dimyati \& Mudjiono. 2013. Belajar Dan Pembelajaran. Jakarta: Rineka Cipta.

Djamarah, Syaful Bahri. 2002. Prestasi Belajar dan Kompetensi Guru. Surabaya: Usaha Nasional.

Fachruddin, Imam. 2009. Desain Penelitian. Malang: Universitas Islam Negeri.

Herrhyanto, Nar dan HM. Akib Hamid. Statistika Dasar. Jakarta: Universitas Terbuka.

Huda, Miftahul. 2012. Cooperative Learning Metode, Teknik, Struktur dan. Model Terapan. Yogyakarta: Pustaka Pelajar.

Imron, Ali. 1995. Pembinaan Guru di Indonesia. Malang: Pustaka Jaya.

Maulandhiyani, Winni Trinita, dkk. 2018. Penerapan Model Pembelajaran Make A Match Untuk Meningkatkan Hasil Belajar Siswa. Jurnal Ilmu Pendidikan Volume 5 Nomor 2.

Nurhidayah, Rina Suryati, dkk. 2017. Penerapan Model Pembelajaran Kooperatif Tipe Make A Match untuk Meningkatkan Hasil Belajar Siswa Pada Materi Keragaman Suku Bangsa Dan Budaya. Jurnal Pena IImiah: Vol 2, No 1.

Rohani, Ahmad. 2004. Pengelolaan Pengajaran. Jakarta: Rineka Cipta.

Sahertian, Piet A \& Ida Aleida Sahertian.1992. Supervisi Pendidikan Dalam Rangka Program Inservice Education. Jakarta: Rineka Cipta.

Sahertian, Piet A. 1994. Profil Guru Prefesional. Yogyakarta: Andi Offset.

Sardiman, A.M. 1988. Interaksi dan Motivasi Belajar-Mengajar Pedoman bagi Guru dan Calon Guru. Jakarta: Rajawali Pers.

Sukmadinata, Nana Syaodih. 2007. Metode Penelitian Pendidikan. Bandung: PT. Remaja Rosda Karya.

Suryabrata, Sumadi. 2000. Pengembangan Alat Ukur Psikologis. Yogyakarta: Andi. 